\title{
E-COMMERCE UNTUK MENDUKUNG BUSINESS TO BUSINESS MENGGUNAKAN DYNAMIC DBMSS: STUDI KASUS PADA PERUSAHAAN DAGANG CROSS TECH
}

\author{
Mohammad Subekti; Anthoni Tandiono; Fenky Tania; Hendro Wibowo A.
}

\author{
Computer Science Department, School of Computer Science, Binus University \\ Jln. K. H. Syahdan No. 9 Palmerah Jakarta Barat 11480 \\ subekti@binus.ac.id
}

\begin{abstract}
The purpose of this study is to develop an e-commerce that can distribute any information about the products of PD Cross Tech. The e-commerce is supported by dynamic DBMS and can be connected via database reseller server so that it can do information sharing. The distribution is performed using the Distributed Relational Database Management System (DRDBMS), supported by the File Transfer Protocol and Virtual Private Network. In other words the e-Commerce supports multiplatform database. Research methodologies used are analytical methods, design methods, and literature study. Results showed that PD Cross Tech needs a new e-Commerce that supports multiplatform database. With this e-Commerce, it is expected that similar computer equipment needs for many organization in Indonesia can be designed in the same way.
\end{abstract}

Keywords: e-commerce, multiplatform database, dynamic DBMS, business to business

\begin{abstract}
ABSTRAK
Tujuan penelitian ini adalah untuk mengembangkan e-Commerce yang dapat mendistribusikan informasi mengenai produk-produk PD Cross Tech. E-commerce ini didukung oleh dynamic DBMS dan dapat terhubung melalui server database reseller sehingga dapat saling berbagi informasi. Pendistribusian dilakukan menggunakanakanakan Distributed Relational Database Management System (DRDBMS) yang didukung dengan File Transfer Protocol dan Virtual Private Network, dalam kata lain e-Commerce yang mendukung multiplatform database. Metodologi penelitian yang digunakanakanakan meliputi metode analisis, metode perancangan, dan studi pustaka. Hasil penelitian menunjukkan bahwa PD Cross Tech membutuhkan suatu eCommerce baru yang mendukung multiplatform database. Dengan dibangunnya e-Commerce ini, diharapkan kebutuhan peralatan komputer yang sama bagi banyak organisasi di Indonesia dapat dirancang dengan cara yang sama.
\end{abstract}

Kata kunci: e-commerce, multiplatform database, dynamic DBMS, business to business 


\section{PENDAHULUAN}

Keberadaan Website dalam e-commerce bertujuan agar para konsumen dapat melakukan transaksi secara online tanpa harus berpergian sehingga dapat menghemat energi, waktu, serta biaya dengan bantuan internet. Selain itu konsumen juga diberikan informasi mengenai spesifikasi dan harga produk tanpa harus mengunjungi lokasi yang menjualnya.

Website dapat mendukung aplikasi Business to Business dan memiliki tingkat keamanan yang baik terutama pada saat pengambilan backup database dari setiap database reseller server yang telah berkerja sama, sehingga diharapkan dapat meningkatkan efektifitas penjualan bebagai produk termasuk produk komputer sebagai lingkup studi penelitian ini. Dan dapat meningkatkan keuntungan perusahaan serta dapat membantu reseller dalam melancarkan proses bisnis dengan kata lain mencipt situasi yang saling menguntungkan satu sama lain.

Secara garis besar Business to Business bekerja menggunakanakanakan sistem dynamic DBMS yang datanya dapat diisi oleh tiap reseller, sehingga memudahkan perusahaan untuk mengontrol dan menawarkan produk yang dibutuhkan oleh distributor secara cepat dan tepat. Dengan kata lain proses business to business ini dapat mempererat hubungan antara reseller dengan perusahaan. Dynamic DBMS (Database Management System) yang digunakanakan dalam website ini merup suatu database yang berbasiskan pada nilai serta memiliki waktu dan lokasi secara spesifik. Jadi database tersebut selalu up to date berdasarkan record yang di-input oleh tiap reseller.

Proses Business to Business didukung bermacam-macam DBMS (Database Management System) sehingga website ini dapat dihubungkan melalui berbagai macam DBMS dengan cara Distributed Relational Database Management System (DRDBMS) yang didukung oleh File Transfer Protocol dan Virtual Private Network. Dapat dikatakan bahwa website e-Commerce ini mendukung multiplatform database. DRDBMS dapat memungkinkan informasi berada pada lokasi baris data yang berbeda (didistribusikan), direferensisilangkan, diperbarui, dan dapat diakses dari semua lokasi sehingga seolah-olah data tersebut berbasis data tunggal dan terpusat.

Pada PD Cross Tech penulis menemukan beberapa permasalahan yang selama ini cukup mengganggu performa perusahaan khususnya tingkat penjualannya. Kasus ini muncul karena ketidakefisienan dalam tugas-tugas divisi Operational Manager dan Marketing Manager. Sering terjadi tugas-tugas yang saling tumpang tindih di antara keduanya. Di bidang keuangan tidak ada prosedur perhitungan biaya pengiriman produk yang terkomputerisasi dan pembagian daerah yang jelas dan tepat bagi reseller sehingga perusahaan merugi karena perhitungan-perhitungan yang tidak akurat. Di sisi lain, khususnya data transaksi bisnis yang melibatkan perusahaan lain tidak di dukung dengan proses pemutakhiran data harian dan tidak adanya relation value berdasarkan waktu dan kegiatan Business to Business pada perusahaan, tidak ada prosedur pembayaran dan pengiriman yang efektif dan efesien bagi reseller, serta masih menggunakanakanakan cara desentralisasi yang mengakibatkan kegiatan Business to Business perusahaan kurang efektif, efesien, dan cepat. Pada proses inventori tidak ada dukungan pendataan proses pembelian stok produk yang terkomputerisasi, tidak ada proses pencatatan produk bergaransi (yang rusak dan tidak dapat diperbaiki lagi) yang terkomputerisasi oleh perusahaan.

Selain permasalahan yang ada tersebut, diperlukan penerapan keamanan sistem yang canggih pada website e-Commerce yang mendukung kegiatan Business to Business antar perusahaan, karena akan diperlukan kerja sama dengan reseller melalui pengaksesan data dari database reseller server yang telah disepakati sehingga perusahaan dapat menawarkan produk kepada reseller lebih cepat dan efesien. 
Dalam rangka mengatasi permasalahan tersebut dan memenuhi berbagai kebutuhan perusahaan, dirancang sistem yang dapat mempermudah proses transaksi bisnis ke bisnis dan dapat menyediakan informasi spesifikasi dan harga peralatan komputer secara rinci dan jelas. Dengan demikian sistem akan dapat menghindari kesulitan bagi konsumen yang ingin bertransaksi secara online maupun secara manual, sehingga dapat diperoleh efektifitas penjualan lebih besar, bertindak cepat dan tepat dalam merespon kebutuhan pasar. Sistem dibuat berbasis internet untuk mendukung proses Business to Business sehingga dapat bersaing secara nasional maupun internasional dan dapat menjangkau seluruh kota di Indonesia dalam menyediakan peralatan komputer.

Dengan pengembangan e-commerce berbasis internet diperoleh manfaat sistem secara menyeluruh yang dapat menghindari kesulitan-kesulitan transaksi bisnis yang ada sekarang menjadi lebih fleksibel dan efisien. Sistem dapat meningkatkan kerja sama dengan para reseller yang ikut terlibat dalam proses Business to Business sehingga perusahaan dapat merespon kebutuhan pasar dengan cepat. Dalam hal ini reseller dan buyer mendapatkan informasi spesifikasi dan harga peralatan komputer secara rinci dan jelas. Dengan demikian perusahaan dapat bersaing dalam tingkat nasional dan internasional melalui website e-Commerce yang dirancang oleh penulis dan tim.

\section{METODE}

\section{E-Commerce}

Menurut Connolly \& Begg (2010: 1027) E-commerce adalah penyebaran, pembelian, penjualan, pemasaran barang dan jasa melalui sistem elektronik seperti internet atau televisi, www, atau jaringan komputer lainnya. e-commerce dapat melibatkan transfer dana elektronik, pertukaran data elektronik, sistem manajemen inventori otomatis, dan sistem pengumpulan data otomatis.

Industri teknologi informasi melihat kegiatan e-Commerce ini sebagai aplikasi dan penerapan dari e-Bisnis (e-Business) yang berkaitan dengan transaksi komersial, seperti: transfer dana secara elektronik, SCM (Supply Chain Management), e-Pemasaran (e-Marketing), atau pemasaran online (online marketing), pemprosesan transaksi online (online transaction processing), pertukaran data elektronik (electronic data interchange /EDI), dll.

E-commerce merupakan bagian dari e-Business, di mana cakupan e-Business lebih luas, tidak hanya sekedar perniagaan tetapi mencakup juga pengkolaborasian mitra bisnis, pelayanan nasabah, lowongan pekerjaan dll. Selain teknologi jaringan www, e-Commerce juga memerlukan teknologi database atau pangkalan data (database), e-Surat atau surat elektronik (e-mail), dan bentuk teknologi non komputer yang lain seperti halnya sistem pengiriman barang, dan alat pembayaran untuk $e$ Commerce ini.

E-Commerce pertama kali diperkenalkan pada tahun 1994 pada saat pertama kali banner elektronik dipakai untuk tujuan promosi dan periklanan di suatu halaman web. Menurut riset Forrester, perdagangan elektronik menghasilkan penjualan seharga US\$12,2 milyar pada 2003. Menurut laporan yang lain pada bulan Oktober 2006 yang lalu, pendapatan ritel online yang bersifat non travel di Amerika Serikat diramalkan mencapai 12.4 triliun dolar US pada tahun 2012 ini. (Connoly, 2010: 1028)

Dalam banyak kasus, sebuah perusahaan e-Commerce bisa bertahan tidak hanya mengandalkan kekuatan produk saja tapi juga adanya tim manajemen yang handal, pengiriman yang tepat waktu, pelayanan yang bagus, struktur organisasi bisnis yang baik, jaringan infrastruktur dan keamanan, desain situs web yang bagus. Beberapa faktor lain yang dapat membuat perusahaan 
bertahan antara lain menyediakan: (1) harga kompetitif; (2) jasa pembelian yang tanggap, cepat, dan ramah; (3) informasi barang dan jasa yang lengkap dan jelas; (4) banyak bonus seperti kupon, penawaran istimewa, dan diskon; (5) perhatian khusus seperti usulan pembelian; (6) rasa komunitas untuk berdiskusi, dan masukan dari pelanggan; (7) kemudahan kegiatan perdagangan.

Beberapa aplikasi umum yang berhubungan dengan e-Commerce, di antaranya e-mail dan Messaging, Content Management Systems, Akunting dan sistem keuangan, Informasi pengiriman dan pemesanan, Pelaporan informasi dari klien dan enterprise, Sistem pembayaran domestik dan internasional, Newsgroup, Online Shopping, Conferencing, dan Online Banking. Perusahaan yang terkenal dalam bidang ini antara lain: eBay, Yahoo, Amazon.com, Google, dan Paypal. Untuk di Indonesia, bisa dilihat Tradeworld.com, Bhineka.com, Fastncheap.com, dll.

\section{Kelebihan e-Commerce}

Dengan e-commerce pembeli dengan fasilitas jaringan internet dapat melakukan kegiatan Entry dokumen, mencetak dokumen pembelian, mengirimkan dokumen faksimile, mengirimkan dokumen asli lewat kurir. Sedangkan dipihak penjual menerima berbagai dokumen order melalui internet atau faksimili, memasukkan ulang yang dikirim melalui faksimili ke database penjualan.

Proses e-commerce diinisialisasi dengan pengenalan bisnis secara electronic pada saat pemakai tersebut memasuki sebuah website. Selanjutnya Cookies dapat membantu operator website untuk mengumpulkan informasi mengenai kebiasaan membeli yang dilakukan oleh sekelompok orang. Informasi ini tidak terhingga nilainya bagi bisnis karena informasi tadi menjadikan pelaku bisnis membuat target periklanannya lebih baik dengan informasi yang lebih baik mengenai demografis.

Keuntungan lainnya bahwa e-Commerce menawarkan pengurangan sejumlah biaya tambahan. Sebuah perusahaan yang melakukan bisnis di internet mengurangi biaya tambahan karena biaya tersebut tidak digunakanakan untuk gedung dan pelayanan pelanggan (customer service), jika dibandingkan dengan jenis bisnis tradisional. Hal ini membantu perusahaan dalam meningkatkan keuntungannya. Salah satu jenis bisnis yang mengambil keuntungan dari e-Commerce adalah perbankan.

Seperti halnya bisnis yang berkeinginan merangkul e-Commerce sebagai suatu cara yang sah untuk melakukan kegiatan bisnis, konsumen juga berkeinginan mengambil keuntungan dari seluruh kemungkinan yang ditawarkan oleh e-Commerce. Keuntungan yang terbesar bagi konsumen adalah melakukan bisnis secara online dengan mudah. Seorang pembeli di internet dapat menggunakanakanakan komputer pribadinya pagi atau malam selama tujuh hari per minggu untuk membeli hampir semua barang. Seorang konsumen tidak perlu mengantri di toko atau bahkan meninggalkan rumahnya yang dilakukan hanya mengklik sebuah produk yang ingin belinya, memasukkan informasi kartu kreditnya, kemudian menunggu produk itu tiba melalui pos. Beberapa perusahaan e-Commerce telah membuat proses ini lebih mudah. Beberapa toko online menyimpan informasi kartu kredit pembelinya di server mereka, sehingga informasi yang dibutuhkan hanya dimasukkan sekali saja. Beberapa bisnis online bahkan tidak mengirimkan produk-produknya ke pelanggan melalui pos, khususnya yang menjual software komputer, produk musik dan film. Sebagai contoh: beyond.com mengizinkan para pelanggannya untuk melakukan download software yang dibelinya langsung ke komputer mereka. Produk-produk lain seperti video dan musik tersedia dengan cara seperti ini pada saat mendatang, sejalan dengan meningkatnya bandwidth dari waktu ke waktu dan waktu download yang meningkat. Contoh keuntungan lain yang ditawarkan oleh e-Commerce ke konsumen adalah pengurangan biaya. Perusahaan yang menjual saham secara online, seperti Etrade.com membebankan biaya hanya sekitar $\$ 10$ per perdagangan, yang jauh lebih murah jika dibandingkan dengan membeli saham tersebut melalui perantara saham tradisional. 


\section{Business to Business}

Bussiness to Business mengambarkan transaksi perdagangan antara perusahaan, seperti antara produsen dan grosir, atau antara grosir dan pengecer. Istilah kontras adalah Business to Consumer dan Business to Goverment. Volume Business to Business transaksi jauh lebih tinggi dibandingkan volume transaksi Business to Consumer (ChaudHury \& Kuilboer: 2002) . Alasan utamanya adalah bahwa dalam rantai pasokan ada transaksi Business to Business yang melibatkan banyak sub komponen atau bahan baku, dan hanya satu transaksi Business to Customer, khususnya penjualan produk jadi ke konsumen. Sebagai contoh, sebuah produsen mobil membuat beberapa transaksi Business to Business seperti membeli ban, kaca untuk jendela, dan selang karet untuk kendaraan. Transaksi terakhirnya, kendaraan selesai dijual ke konsumen, yang disebut transaksi tunggal (Business to Customer).

Business to Business juga digunakanakan dalam konteks komunikasi dan kolaborasi. Banyak perusahaan sekarang menggunakan media sosial untuk menghubungkan dengan konsumen mereka (Business to Customer), namun mereka sekarang menggunakan alat serupa dalam bisnis sehingga karyawan dapat terhubung dengan satu sama lain. Ketika komunikasi terjadi antara karyawan, ini dapat disebut sebagai komunikasi "Business to Business".

\section{Dynamic DBMS}

Dynamic database berbasis Web menurut Connoly (2010: 1034), adalah Database dengan hubungan "berbasis nilai" dimana biasanya ditentukan pada penemuan catatan pengambilan waktu dan lokasi yang terkait selama pengambilan data. DRDBMS memungkinkan informasi berada pada baris data di lokasi yang berbeda (didistribusikan), dan direferensi silangkan, diperbaharui, dan akses dari semua lokasi, seolah-olah data tersebut berbasis data tunggal dan terpusat.

\section{HASIL DAN PEMBAHASAN}

\section{Analisis Sistem Berjalan}

Sistem ini dikembangkan pada PD Cross Tech yang begerak dalam industri perangkat komputer. Sistem yang dijelaskan merupakan suatu sistem perusahaan (lihat Gambar 1.) dengan bebagai prosedu dan pemasalahan yang ada. Sistem ini memiliki tujuh primary actor yang mempunyai tugasnya masing-masing yaitu: Reseller, Buyer, Inventory, Operational Manager, Finance Manager, Direktur Utama, dan Supplier. Proses terjadinya kegiatan bisnis ini bermula dari supplier menawarkan produk kepada perusahaan yang direspon oleh Direktur Utama. Direktur Utama memesan produk sesuai dengan data yang diperoleh dari manager pada saat rapat.

Selanjutnya supplier mengantarkan produk tersebut kepada perusahaan yang memesan dan kemudian diterima oleh bagian Inventory perusahaan. Inventory memberikan konfirmasi kepada Operational Manager mengenai jumlah dan produk apakah yang telah diterimanya sehingga Operational Manager dapat melakukan update pada website sehingga buyer dan reseller dapat melihat daftar produk terkini. Pada saat melakukan update website, disamping itu Operational Manager menawarkan produk kepada buyer dan reseller, apabila mereka tertarik dengan penawaran tersebut maka buyer dan reseller dapat memesan produk dan membayarnya melalui transfer bank atau COD (Cash On Delivery).

Proses pemesanan tersebut dimulai pada saat reseller dan buyer melihat penawaran produk melalui website Kaskus dan Indowebster yang telah di-update oleh Operational Manager. Reseller dan buyer memesan produk dapat melalui SMS ataupun melalui konten website tersebut. Apabila 
memesannya melalui SMS, reseller dan buyer direspon langsung oleh Marketing Manager dan dikonfirmasikan balik melalui SMS kepada reseller dan buyer apabila memesannya melalui konten website Kaskus dan Indowebster maka direspon langsung oleh Operational Manager dan memberikan konfirmasi kepada Marketing Manager mengenai pemesanan produk tersebut kemudian pemesanan tersebut dikonfirmasikan balik dari Marketing Manager oleh Operational Manager kepada reseller dan buyer melalui konten website tersebut. Sedangkan proses pembayaran dimulai dengan kegiatan memilih produk, melakukan pembayaran melalui transfer bank atau COD (Cash On Delivery) yang direspon oleh Marketing Manager.

Pembayaran dapat melalui transfer bank atau COD. Pembayaran melalui transfer bank, prosesnya dimulai pada saat reseller dan buyer melakukan pembayaran melalui transfer bank ke rekening perusahaan yang direspon oleh Finance Manager. Selanjutnya reseller dan buyer memberikan konfirmasi pembayaran melalui website yang diterima oleh Operational Manager. Operational Manager memberikan konfirmasi pembayaran tersebut kepada Finance Manager.

Reseller dan buyer juga dapat memberikan konfirmasi pembayaran melalui SMS yang ditujukan kepada Marketing Manager. Selanjutnya Marketing Manager memberikan konfirmasi mengenai pemberitahuan pembayaran tersebut kepada Finance Manager. Finance Manager menerima konfirmasi tersebut kemudian memeriksa di rekening perusahaan untuk memastikan bahwa reseller dan buyer tersebut telah membayar dan memberitahukan Marketing Manager untuk memberitahukan kepada Inventory tentang konfirmasi pembayaran pesanan produk.

Pembayaran melalui COD, prosesnya dimulai pada saat reseller dan buyer membuat janji untuk bertemu dengan Marketing Manager disuatu tempat dimana dilakukan transaksi pembayaran dan serah terima produk. Marketing Manager merespon dengan memberikan konfirmasi tempat dimana mereka bertemu. Pada saat bertemu, reseller atau buyer melakukan pembayaran pemesanan produk kepada Marketing Manager.

Setelah memesan dan membayarnya kepada bagian Marketing Manager, bagian tersebut memberikan konfirmasi kepada Inventory bahwa buyer atau reseller tersebut telah melakukan pembayaran dan Inventory mengirimkan produk. Pengiriman dibed menjadi dua, yaitu pengiriman melalui pembayaran via transfer bank dan COD. Proses pengiriman melalui pembayaran via transfer bank dimulai pada saat Marketing Manager memberikan konfirmasi pembayaran produk kepada Inventory kemudian Inventory menkonfirmasikan produk yang dipesan oleh reseller atau buyer melalui website dan SMS kepada Marketing Manager.

Setelah melakukan konfirmasi tersebut kemudian Inventory mengirimkan produk yang telah dipesan dan dibayar melalui kurir. Kurir yang dimaksudkan bukan merup bagian dari divisi perusahaan, melainkan suatu perusahaan lain yang menyedi jasa pengiriman barang seperti JNE. Setelah menerima produk, reseller dan buyer diminta oleh perusahaan untuk memberikan testimonial ataupun feedback melalui website baik berupa kritik maupun saran yang dapat membantu serta menjadikan perusahaan ini menjadi lebih baik.

Sedangkan proses pengiriman melalui pembayaran via COD dimulai pada saat Marketing Manager telah menerima uang pembayaran dari reseller atau buyer pada tempat dimana mereka janji untuk bertemu kemudian menyerahkan produk pada saat itu juga. Sesudah menyerahkan produk tersebut, Marketing Manager kembali ke perusahaan dan memberikan uang pembayaran yang diterimanya kepada Finance Manager untuk disimpan ke dalam rekening perusahaan dan mencatat data transaksi tersebut dan kemudian dimasukkan ke dalam laporan keuangan perusahaan yang diberikan kepada Operational Manager dan dibaca oleh Direktur utama pada saat rapat.

Inventory juga melakukan tugasnya dalam memeriksa jumlah sisa stok kemudian memberitahukan kepada Operational Manager sehingga Operational Manager dapat membuat 
laporan dan memberikannya kepada Direktur Utama pada saat rapat manager yang diad seminggu sekali. Finance Manager melakukan pembayaran kepada supplier apabila deadline pembayaran sudah dekat.

Proses pembuatan dan pemberian laporan dimulai pada saat Marketing Manager memberikan laporan penjualan dan kegiatan promosi kepada Operational Manager. Inventory memberikan data stok produk kepada Operational Manager, Repair Team memberikan data produk bergaransi yang tidak dapat diperbaiki kepada Operational Manager dan Finance Manager memberikan laporan keuangan kepada Operational Manager sehingga Operational Manager dapat membuat laporan manager untuk Direktur Utama.

Operational Manager memberikan laporan manager kepada Direktur Utama pada saat rapat. Direktur Utama membaca laporan tersebut yang telah disusun oleh Operational Manager serta membuat keputusan yang berkaitan dengan langkah-langkah yang baik bagi perusahaan ini dan menyampaikan kepada seluruh manager. Selanjutnya Direktur Utama dapat menentukan produk apa saja yang harus dipesan berdasarkan data yang diberikan oleh Operational Manager. Proses pembelian produk dimulai pada saat Inventory melakukan pemeriksaan terhadap sisa stok produk yang ada untuk disampaikan kepada Operational Manager.

Operational Manager memberitahukan sisa stok produk ke dalam bentuk laporan untuk disampaikan kepada Direktur Utama pada saat rapat. Direktur Utama memesan produk dari supplier sesuai dengan laporan yang diberikan pada saat rapat. Inventory menerima produk yang telah dipesan oleh Direktur Utama melalui supplier dan memberitahukan jumlah stok produk kepada Operational Manager. Operational Manager mencatat jumlah stok yang telah diterimanya dari Inventory ke dalam sebuah note. Inventory memberikan data yang berisi deadline pembayaran kepada Finance Manager selaku yang mengatur keuangan perusahaan. Finance Manager membayar produk yang telah dipesan dan diterima dari supplier sesuai dengan deadline pembayarannya.

\section{Solusi Sistem Baru}

Sistem ini berisi proses-proses cara kerja perusahaan secara umum. Cara kerja sistem tersebut dimulai pada saat supplier menawarkan produk kepada perusahaan yang direspon oleh direktur utama. Direktur utama memesan stok produk yang dibutuhkan selanjutnya supplier mengantarkan produk yang dipesan tersebut kemudian diterima oleh bagian Inventory. Inventory memeriksa dan melakukan update stok produk kepada Operational Manager dan melakukan update pada website e-Commerce. Ilustrasi sistem dapat dilihat pada Gambar 1.

Proses jual beli terjadi ketika reseller atau buyer mengakses website e-Commerce dan memesan produk yang diinginkan. Untuk reseller diberikan fasilitas khusus yaitu dapat meregistrasi menjadi member melalui website tersebut dan dapat melakukan share database yang dimiliki antara reseller dengan perusahaan sehingga dapat membantu perusahaan dalam kegiatan bisnis jual beli. Proses share database dilakukan ketika Operational Manager menghubungkan server database yang dimiliki oleh reseller dan memeriksa backup database yang telah disepakati untuk dapat diambil oleh perusahaan.

Operational Manager melakukan update data pada database perusahaan berdasarkan data dari reseller dan menawarkannya produk-produk berdasarkan data yang telah diambil. Reseller dapat memesan produk yang telah ditawarkan dan buyer dapat memesan produk yang ditampilkan melalui website ini. Setelah pemesanan produk, reseller atau buyer dapat melakukan pembayaran yang direspon oleh Operational Manager (bila yang melakukan pembayaran adalah reseller) sedangkan Marketing Manager (bila yang melakukan pembayaran adalah buyer). 
Bila pembayaran telah diterima maka Marketing Manager dan Operational Manager memberikan konfirmasi ke Inventory untuk dapat mengirimkan produk yang dipesan oleh buyer atau reseller. Setelah itu, Operational Manager memeriksa stok produk dengan dibantu oleh Inventory yang kemudian melaporkannya kepada Direktur utama. Direktur utama memesan stok produk yang dibutuhkan kepada supplier.

Supplier menagih pembayaran terhadap produk yang belum dibayar oleh perusahaan yang direspon oleh bagian Finance Manager. Operational Manager membuat laporan dan memberikan kepada direktur utama pada saat rapat sehingga dengna begitu direktur utama dapat menentukan langkah terbaik selanjutnya.

\section{Prosedur Pemesanan Produk}

Prosedur ini menjelaskan pemesanan produk secara rinci dan jelas. Cara kerjanya dimulai pada saat buyer dan reseller melihat produk melalui website. Buyer dapat memesan melalui SMS ataupun telepon yang direspon oleh Marketing Manager sedangkan Reseller dapat memesan melalui website yang direspon oleh Operational Manager sehingga Marketing Manager dapat fokus terhadap tugas lainnya seperti kegiatan promosi perusahaan dan menangani buyer secara cepat dan tepat.

Setelah buyer dan reseller melakukan pembayaran produk yang dipesan, Marketing Manager memberi konfirmasi kepada buyer melalui SMS atau telepon sedangkan Operational Manager memberikan konfirmasi kepada reseller melalui website.

\section{Prosedur Pembayaran (bagi Reseller)}

Prosedur ini menjelaskan pembayaran bagi reseller secara rinci dan jelas. Hal ini sesuai dengan poin permasalahan, yang menyebutkan bahwa diperlukannya suatu sistem pembayaran khusus bagi reseller karena reseller lebih sering memesan produk secara grosir sehingga pembayaran melalui COD (Cash On Delivery) tidak efektif. Prosedur kegiatan ini dimulai pada saat reseller membayar biaya pemesanan via transfer bank yang diterima oleh Finance Manager. Finance Manager memberikan konfirmasi pembayaran produk yang dipesan oleh reseller kepada Operational Manager untuk diupdate status pembayaran reseller dan memberitahukan kepada bagian Inventory tentang status tersebut. Selanjutnya Inventory mengirim pesanan tersebut kepada reseller.

\section{Prosedur Pembayaran (bagi Buyer)}

Prosedur ini menjelaskan pembayaran bagi buyer secara rinci dan jelas. Sistem ini dimulai pada saat buyer memesan produk. Buyer memilih tipe pembayaran secara transfer bank maka direspon oleh Finance Manager dengan memeriksa pembayaran pada rekening perusahaan agar dapat ditindaklanjuti oleh Marketing Manager. Apabila buyer memilih tipe pembayaran secara Cash On Delivery maka direspon oleh Marketing Manager dengan dilakukan kesepakatan dalam menentukan waktu dan tempat untuk bertemu.

\section{Prosedur Pembayaran via Transfer (bagi Buyer)}

Prosedur ini menjelaskan sistem pembayaran via transfer bagi buyer secara rinci dan jelas. Prosedur ini dimulai pada saat buyer melakukan pembayaran produk melalui transfer bank yang diterima oleh Finance Manager selanjutnya buyer memberikan konfirmasi kepada Marketing Manager mengenai pembayaran produk yang telah dilakukannya. 


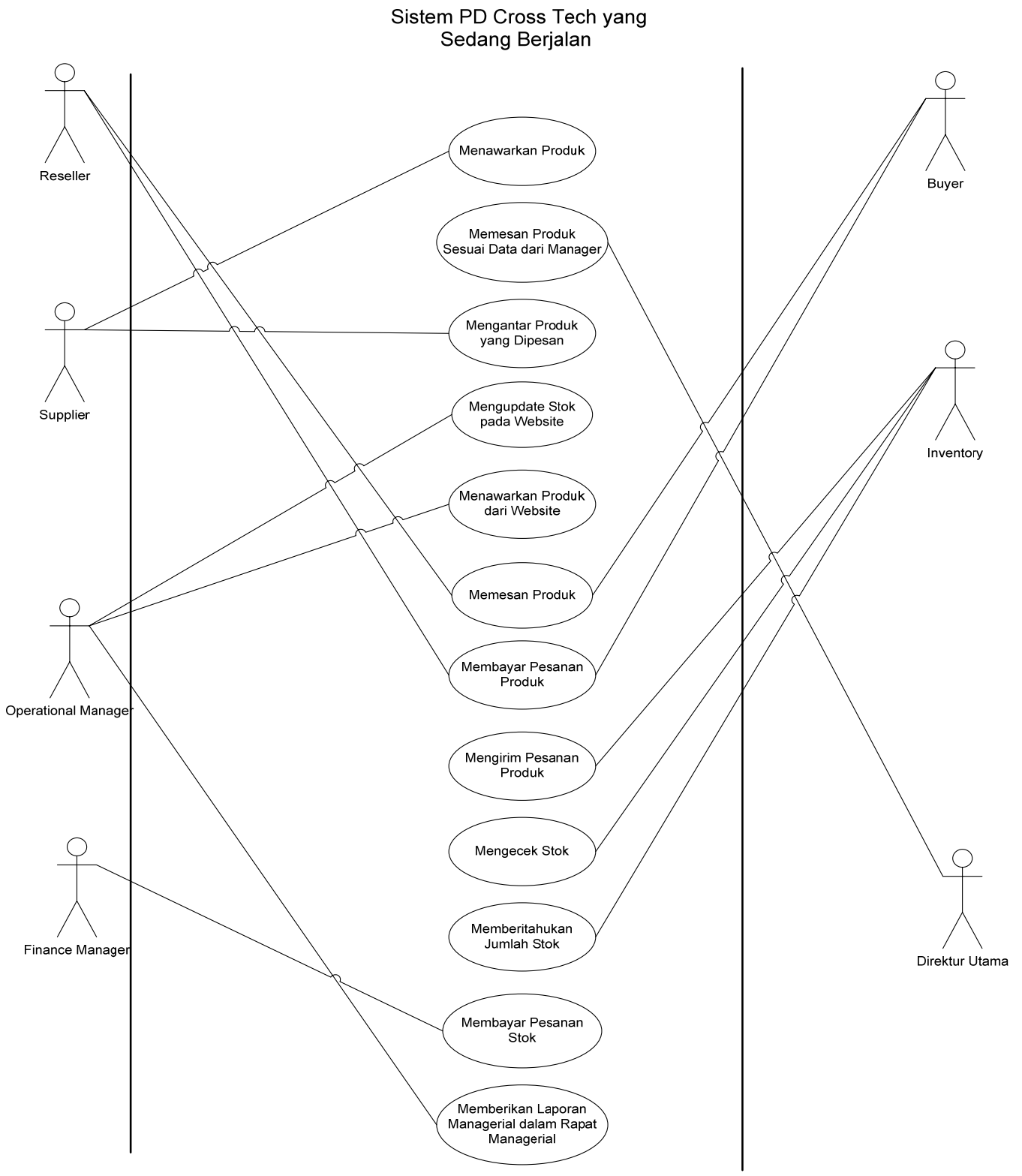

Gambar 1. Use case diagram sistem.

Marketing Manager memberikan konfirmasi kepada Finance Manager mengenai adanya transaksi pembayaran tersebut dan memeriksa pada rekening perusahaan. Selanjutnya Finance Manager menkonfirmasikan adanya transaksi pembayaran tersebut apabila sudah tercantum di rekening perusahaan dan memberitahukannya kepada Marketing Manager. Setelah mendapatkan konfirmasi dari Finance Manager mengenai transaksi pembayaran tersebut maka Marketing Manager memberitahukan hasil konfirmasi tersebut kepada Operational Manager yang kemudian disampaikan kepada Inventory sehingga Inventory dapat mengirimkan produk yang dipesan. Selanjutnya Operational Manager mengisi data pembayaran ke dalam database.

\section{Prosedur Pembayaran via Cash On Delivery (bagi Buyer)}

Poses ini menjelaskan pembayaran via cash on delivery bagi buyer secara rinci dan jelas. Sistem tersebut dimulai pada saat buyer membuat kesepakatan dengan Marketing Manager untuk 
bertemu pada suatu tempat. Marketing Manager menkonfirmasikan waktu dan tempat untuk bertemu dengan buyer. Pada saat bertemu, buyer melakukan pembayaran secara langsung kepada Marketing Manager. Setelah menerima pembayaran tersebut, Marketing Manager menghubungi Operational Manager untuk memberitahukan bahwa buyer sudah melakukan pembayaran. Selanjutnya Operational Manager dapat mengisi data mengenai pembayaran ke dalam database.

\section{Prosedur Pengiriman Produk (Pembayaran via Transfer)}

Prosedur ini menjelaskan pengiriman produk yang dibayar melalui transfer secara rinci dan jelas. Sistem tersebut dimulai pada saat Operational Manager memberikan konfirmasi status pembayaran kepada Inventory. Setelah Inventory mendapatkan konfirmasi tersebut, kemudian mengirimkan produk yang dipesan melalui kurir untuk sampai ke reseller. Hal ini sesuai dengan poin permasalahan pada, perihal tentang diperlukannya suatu sistem pengiriman produk yang sesuai bagi reseller karena reseller memesan produknya dalam jumlah banyak sehingga pembayaran secara cash on deliver (COD) tidak efektif.

Inventory menkonfirmasi status pembayaran produk yang dipesan kepada Operational Manager yang diperolehnya dari Marketing Manager. Selanjutnya Inventory mengirimkan produk tersebut melalui kurir untuk sampai kepada buyer. Reseller memiliki hak untuk memberikan testimonial kepada perusahaan melalui website yang telah dirancang oleh penulis dan direspon langsung oleh Operational Manager.

\section{Prosedur Pengiriman Produk (Pembayaran via Cash on Delivery)}

Prosedur ini menjelaskan pengiriman produk yang dibayar melalui cash on delivery secara rinci serta dimulai pada saat buyer melakukan kesepakatan dengan Marketing Manager untuk dapat bertemu di suatu tempat dan selanjutnya melakukan transaksi. Selanjutnya Marketing Manager menerima uang pembayaran produk dan memberikan produk tersebut kepada buyer. Setelah itu Marketing Manager memberikan uang tersebut kepada Finance Manager selaku yang bertugas mengatur keuangan perusahaan dan membuat laporan keuangan perusahaan sehingga ada pencatatan data keuangan dan memberikannya kepada Operational Manager pada saat rapat. Hal mengenai laporan data dibahas lebih detail pada sistem pemberian laporan.

\section{Prosedur Share Database Multiplatform}

Sistem ini menjelaskan share database perusahaan secara rinci yang sesuai dengan poin permasalahan tentang diperlukannya melakukan share data dari database reseller (multiplatform) sehingga perusahaan dapat bersaing secara nasional dan internasional. Prosedur ini dimulai pada saat Operational Manager menghubungkan antara internet dengan server database reseller dan server database reseller dengan Distributed Relational Database Management System (DRDBMS) yang didukung oleh File Transfer Protocol (FTP) dan Virtual Private Network (VPN).

Selanjutnya Operational Manager membuka server database reseller yang telah disepakati sebelumnya untuk dapat melihat serta mengambil backup database dari server database reseller. Selanjutnya perusahaan dapat menawarkan produk yang sering terjual kepada reseller melalui Operatinal Manager berdasarkan backup database yang telah diambil. Arsitektur share data digambarkan pada Gambar 2.

\section{Prosedur Garansi}

Prosedur ini menjelaskan garansi secara rinci serta sistem ini dimulai pada saat reseller dan buyer memberikan produk yang bermasalah dan masih bergaransi kepada Repair Team. 
Repair team memeriksa produk tersebut apakah rusak atau tidak. Apabila produk tersebut tidak rusak maka dikembalikan kepada pemiliknya. Bila rusak maka repair team memeriksa apakah dapat perbaiki atau tidak, bila produk tersebut dapat diperbaiki maka repair team memperbaikinya. Tetapi apabila produk tersebut rusak dan tidak dapat diperbaiki maka repair team menggantikan produk tersebut dengan produk yang baru. Selanjutnya repair team memberitahukan kepada Operational Manager untuk dapat memasukkan data produk yang rusak dan tidak dapat diperbaiki lagi serta produk yang diganti baru (selama masih dalam masa garansi) ke dalam database.

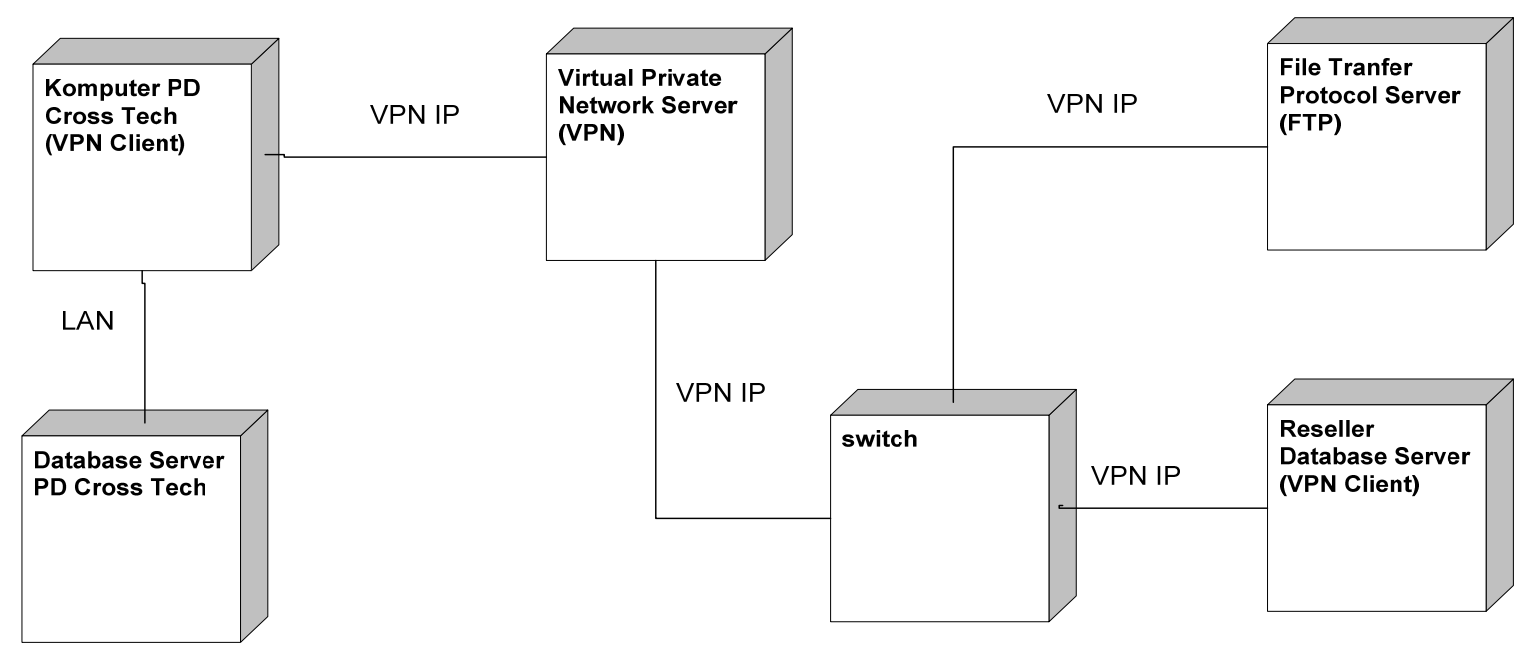

Gambar 2. Arsitektur share database server-reseller.

Hal tersebut sesuai dengan poin permasalahan tentang diperlukan suatu pencatatan produk yang rusak maupun yang tidak dapat diperbaiki secara komputerisasi sehingga dapat dilakukan pemeriksaan secara efektif dan efesien.

Perusahaan memberikan garansi pada beberapa produk tertentu. Apabila ada produk yang oleh perusahaan tidak diberikan garansi dan suatu ketika produk tersebut rusak (tanpa cacat fisik) maka produk tersebut masih mempunyai garansi resmi dari supplier. Apabila produk tersebut dibeli langsung dari perusahaan maka perusahaan dapat menjadi perantara untuk menghubungkan ke supplier. Supplier lebih mengutam pelayanan terhadap produk yang masih bergaransi maupun produk yang diperbaiki atau diganti dengan produk yang baru. Hal tersebut tergantung dari kebijaksanaan supplier.

\section{Prosedur Pembelian Stok Produk}

Prosedur ini menjelaskan pembelian stok produk secara rinci. Sistem ini dimulai pada saat Inventory memeriksa jumlah sisa stok produk dan memberitahukannya kepada Operational Manager. Operational Manager mencatat ke dalam laporan dan memberikannya kepada direktur utama pada saat rapat. Hal ini dibahas lebih detail dalam sistem pemberian laporan. Direktur utama memesan produk dari supplier berdasarkan data laporan yang diterima dari Operational Manager. Selanjutnya Inventory menerima produk yang dipesan oleh direktur utama kepada supplier dan memberitahukan kepada Operational Manager tentang penerimaan produk tersebut.

Operational Manager mencatat ke dalam database mengenai jumlah stok produk yang sudah diterima oleh Inventory dari supplier. Hal ini sesuai dengan poin permasalahan tentang diperlukan suatu pemeriksaan stok produk secara komputerisasi melalui database sehingga memudahkan pemeriksaan jumlah stok produk. 
Inventory memberitahukan kepada Finance Manager tentang data dan deadline pembayaran terhadap produk yang dipesan oleh direktur utama ke supplier. Selanjutnya Finance Manager melakukan pembayaran tersebut kepada supplier. Operational Manager mengubah status pembayaran stok produk apabila Finance Manager sudah melakukan pembayaran.

\section{Prosedur Pembuatan Laporan}

Prosedur ini sama dengan Prosedur Pembuatan Laporan yang sedang berjalan karena penulis tidak melihat adanya yang perlu diperbaiki atau ditambahkan dari sistem tersebut.

\section{Sistem Pendukung Website e-Commerce}

Dynamic DBMS - penulis merekomendasikan penggunaan dynamic DBMS sebagai sistem pengelolaan database pada website e-Commerce perusahaan. Pemakaian dynamic DBMS dikarenakan perlu adanya suatu sistem pengolahan database yang berorientasi pada value atau nilai yang berhubungan dengan pencatatan waktu, tempat dan aktivitas pada saat melakukan update database sehingga perusahaan ini dapat memeriksa, menjalankan dan mengembangkan kegiatan Business to Business yang efisien dan cepat.

Proses perhitungan biaya pengiriman - proses ini memiliki beberapa atribut yang penting seperti tujuan dan biaya pengiriman yang disesuaikan dengan bobot produk serta lamanya waktu pengiriman untuk sampai ke tujuan. Atribut-atribut tersebut berasal dari data jasa pengiriman barang seperti JNE. Sistem perhitungan biaya pengiriman tersebut dibuat karena reseller terkadang tidak semuanya mengetahui lokasi tempat reseller berada sehingga sering terjadi kesalahan dalam biaya pengiriman.

Penerapan keamanan - sistem yang digunakan dalam website ini adalah password yang telah dienkripsi, penggunaan HTTPs pada web server dan penggunaan Virtual Private Network (VPN) untuk membuat tunnel yang aman pada saat terhubung ke server database reseller. Desentralisasi selama ini perusahaan menggunakan arsitektur semi desentralisasi. Semi desentralisasi adalah dimana manager dapat mengatur para divisi mereka tetapi direktur utama juga dapat mengatur divisi dari para manager sehingga menjadi tidak efektif dalam pengambilan keputusan. Oleh karena itu, penulis menyarankan penggunaan sistem desentralisasi secara penuh sehingga perusahaan dapat berjalan dengan lancar, cepat dan efektif. Dengan sistem ini para manager dapat mengatur divisinya lebih efektif, cepat dan tanggap terhadap perubahan pada pasar sedangkan direktur utama hanya mengawasi dan mengontrol perusahaan melalui para manager.

\section{PENUTUP}

Sistem e-Commerce menggunakan Dynamic DBMS. Dynamic DBMS merupakan suatu database yang "berbasis nilai" dimana biasanya ditentukan pada penemuan catatan pengambilan waktu dan lokasi yang terkait. Dalam website ini mempunyai sistem penawaran produk yang terkomputerisasi dan terhubung dengan database.

Website dapat mendukung sistem yang terkomputerisasi khususnya dalam perhitungan biaya pengiriman produk kepada reseller dan pembayaran melalui via transfer (khusus bagi reseller) serta pencatatan stok produk yang telah dipesan ataupun diterima oleh perusahaan dan juga pencatatan produk bergaransi yang rusak maupun yang tidak dapat diperbaiki.

Penerapan keamanan sistem seperti password untuk login yang telah dienkripsi, penggunaan HTTPs dan penggunaan Virtual Private Network untuk memberikan enkripsi pada jalur yang dilalui 
oleh backup database yang diambil melalui server database reseller.

Perusahaan ini masih memakai arsitektur semi desentralisasi sehingga kurang efektif, efesien dalam melaksan kegiatan Business to Business. Semi desentralisasi adalah suatu sistem yang memungkinkan para manager mengatur divisi mereka sendiri tetapi direktur utama masih mengatur, mengawasi dan mengontrol semua kegiatan divisi perusahaan yang menyebabkan tidak efesiennya kegiatan perusahaan. Oleh karena itu perusahaan dianjurkan untuk memakai sistem desentralisasi secara total dan membuat suatu pembagian kerja yang efesien antara Marketing Manager dan Operational Manager.

Perusahaan mempunyai kerja sama dengan reseller dalam hal pengaksesan backup database reseller (dalam kata lain sistem perusahaan ini sudah mendukung multiplatform database) sehingga perusahaan dapat menawarkan produknya kepada reseller dengan cepat dan efesien

Berdasarkan kesimpulan di atas, ada beberapa saran yang dapat penulis ajukan agar sistem perusahaan ini dapat berjalan dengan baik. Untuk lebih efektifnya, pengembangan dan implementasi selanjutnya antara lain: (1) diperlukannya sosialisasi website e-Commerce terhadap semua pengguna (reseller dan buyer) yang terlibat agar sistem yang ada dapat bermanfaat; (2) website e-Commerce yang dirancang masih tidak efisien sehingga dibutuhkan optimasi terhadap query statement dan coding untuk mempercepat kinerja website; (3) diperlukannya suatu pengembangan DBMS seperti oracle nantinya pada kegiatan business to business karena kegiatan perusahaan ini sangat bergantung pada ketersediaan data, oracle mempunyai kemampuan yang sangat baik pada recovery data dan backup data bila terjadi kehilangan data pada server perusahaan

\section{DAFTAR PUSTAKA}

ChaudHury, Abhijit \& Kuilboer, Jean-Pierre. (2002). E-Bussiness and E_Commerce Infrastructure: Technologies Supporting The e-Business Initiative (international edition). New York: McGraw-Hill.

Connolly, T.M. and Begg, C.E. (2010). Database Systems: a Practical Approach to Design, Implementation and Management ( $5^{\text {th }}$ edition). Harlow: Addison Wesley. 